Reviews Studia luridica Lublinensia vol. XXVIII, 2, 2019 DOI: $10.17951 /$ sil.2019.28.2.217-220

Wojciech Taras

Uniwersytet Marii Curie-Skłodowskiej w Lublinie ORCID: 0000-0001-9643-8282 wojtar@poczta.umcs.lublin.pl

\title{
Michał Frączkiewicz, Małgorzata Terlikowska, Ustawa o samorzacdowych kolegiach odwoławczych. Komentarz, Warszawa 2019, Ss. XVI + 106
}

Scholastyczna metoda nauczania prawa oraz analizy i syntezy kanonicznych tekstów prawnych zapoczątkowała proces wyodrębniania się dwóch zasadniczych, obok traktatu naukowego, form wypowiedzi prawników: glosy do aktu stosowania prawa oraz komentarza do aktu prawnego ${ }^{1}$. Współcześnie w niektórych środowiskach prawniczych prestiż określonej osoby ocenia się nie tylko w świetle dorobku w postaci typowych prac naukowych, nierzadko pisanych dla uzyskania kolejnego stopnia awansu zawodowego, lecz także na podstawie biegłej znajomości obowiązujących przepisów prawnych i ich wykładni ujętej w formę komentarza do aktu o wysokiej mocy prawnej. Przedmiotem nauki prawa są przecież jego obowiązujące normy, a podstawowym zadaniem dogmatyki staje się ich wyjaśnianie i uzupełnianie dla celów bezproblemowego stosowania przepisów w praktyce. Nie można z tej przyczyny dziwić się, że półki księgarskie pełne są tomów komentarzy do kodeksów, ustaw wiodących i ustrojowych, w tym całkiem niedawno opublikowanych; zdumiewać może jedynie ich mocno zróżnicowana przydatność praktyczna.

Recenzowany komentarz do ustawy z dnia 12 października 1994 r. o samorządowych kolegiach odwoławczych ${ }^{2}$ jest kolejny na rynku wydawniczym po opracowaniu przygotowanym przez pracowników Katedry Prawa Administracyjnego i Nauki o Administracji UMCS w Lublinie ${ }^{3}$. Łączy je pewna cecha, a mianowicie

\footnotetext{
1 Zob. w szerszym kontekście: H.J. Berman, Prawo i rewolucja. Ksztaltowanie się zachodniej tradycji prawnej, Warszawa 1995, s. 195-206.

2 T.j. Dz.U. 2018, poz. 570.

3 A. Ostrowska, K. Sikora, Ustawa o samorzadowych kolegiach odwoławczych. Komentarz, Warszawa 2012.
} 
nie zostały one napisane przez członków tych specyficznych organów odwoławczych. Uważam, że komentarz do aktu prawnego powinien stanowić pogłębione źródło wiedzy dla osób zajmujących się rozstrzyganiem problemów wynikających z realizacji i stosowania analizowanych przepisów, a tym samym komentator powinien dysponować nie mniejszą znajomością stosunków społecznych regulowanych danym aktem prawnym niż praktyk, w przeciwnym razie komentarz staje się prostym przytoczeniem treści przepisów prawnych bez odniesienia do rzeczywistości społecznej.

Recenzowane opracowanie zostało ujęte w klasyczną formę komentarza do 35 artykułów wspomnianej wyżej ustawy, z pominięciem przepisów zmieniających i wygasłych, według stanu prawnego na luty 2019 r. Po numerze jednostki redakcyjnej i skrótowym przywołaniu treści przepisu wskazano jego powiązanie z innymi przepisami tej ustawy oraz z przepisami innych aktów prawnych (np. Ordynacji podatkowej czy ustawy o służbie cywilnej). Następnie umieszczono treść autorskiego komentarza, podzielonego na punkty, oraz w niektórych przypadkach dokonano wyboru tez orzeczeń Sądu Najwyższego i sądów administracyjnych obu instancji; zamieszczono też przykładowe wzory pism procesowych. Ponadto w odrębnych ramkach podkreślono istotność wyrażonych w tekście twierdzeń i wniosków. Można odnotować jedynie niewielką usterkę - otóż pkt 3 komentarza do art. 24 (s. 99) powinien zostać przeniesiony do art. 25-28 ustawy (s. 101), ponieważ dotyczy pominiętych przepisów zmieniających.

Komentarz właściwie nie ma wprowadzenia, trudno bowiem za takie uznać kilka zdań na s. XV. Czytelnik nie zapozna się więc z procesem kształtowania się koncepcji organu odwoławczego od decyzji organów gminy w trakcie prac nad ustawą o samorządzie terytorialnym, przyczynami przekształcenia w 1994 r. kolegiów odwoławczych przy sejmikach samorządowych w samorządowe kolegia odwoławcze; nie będzie też miał możliwości samodzielnego zaznajomienia się z literaturą przedmiotu, gdyż jej wybór zamieszczony na s. XIII jest dość ograniczony. Jak zarysowano powyżej, główny zarzut, jaki należy podnieść przeciwko recenzowanemu opracowaniu, to brak pogłębionych rozważań o wymiarze praktycznym, niemniej nie sposób autorom odmówić trafności szeregu wniosków. Warto wymienić choćby następujące spostrzeżenia: kolegia pełnią funkcję ochronną obywateli przed wadliwymi decyzjami samorządu terytorialnego (s. 9); nadzór Prezesa Rady Ministrów nie dotyczy działalności orzeczniczej kolegiów (s. 19); liczba członków kolegium uzależniona jest od jego budżetu (s. 24); nie istnieje racjonalne uzasadnienie dla zróżnicowania zakazów łączenia stanowisk członków etatowych i pozaetatowych (s. 44); powołanie członka etatowego istotnie różni się od sposobu nawiązania stosunku pracy określonego w Kodeksie pracy (s. 56-57).

Krytykę treści zawartych w recenzowanym komentarzu można prowadzić na różnych płaszczyznach. Ograniczę się w tym miejscu tylko do trzech zagadnień. Pierwsze odnosi się do stałej bolączki organów kolegialnych, a mianowicie do 
pominięcia podpisu jednego z członków składu orzekającego na dokumencie urzędowym. W komentarzu wskazano, że decyzja niepodpisana przez jednego członka dotknięta jest wadą kwalifikowaną, następnie zaś przytoczono rozbieżne tezy wyroków dwóch wojewódzkich sądów administracyjnych (s. 86-87). Należy jednak odróżnić dwie sytuacje: 1) gdy na wszystkich egzemplarzach wydanego rozstrzygnięcia brakuje podpisu choćby jednego członka oraz 2) gdy jedynie egzemplarz doręczony jednej ze stron nie został podpisany przez wszystkich członków składu orzekającego. W pierwszym przypadku bezsprzecznie dojdzie do wydania decyzji z rażącym naruszeniem prawa, lecz w drugim już tylko do nieistotnego naruszenia przepisów postępowania, i to w sposób niewpływający na wynik sprawy.

Kolejny problem dotyczy wprowadzenia do ustawy z 1994 r. odpowiedzialności dyscyplinarnej członków kolegium (s. 62-84). Komentarz w sporej części sprowadza się do przytoczenia treści odpowiedniego rozporządzenia wykonawczego, jednakże dotyka również spornych kwestii, jak np. pojęcie obowiązków służbowych i godności zawodowej. Poza zakresem rozważań pozostała natomiast fundamentalna kwestia sensowności powoływania w każdym z 49 kolegiów własnej komisji dyscyplinarnej złożonej z trzech etatowych członków. Oznacza to, że w komisjach zasiada 147 członków dla ewentualnego rozpatrzenia deliktów dyscyplinarnych ponad 500 członków etatowych i ok. 700 pozaetatowych. Niektóre kolegia nie mają licznej obsady kadrowej, w związku z tym może dojść do przymusowej sytuacji rozpatrzenia sprawy swojego kolegi, a to z pewnością nie wpłynie pozytywnie na obiektywizm orzekania i poziom morale pozostałych członków kolegium. W związku z tym w literaturze przedmiotu zgłoszono postulat stworzenia kilku komisji dyscyplinarnych pierwszej instancji w sprawach członków 10-12 kolegiów ${ }^{4}$.

Ostatnie zagadnienie wiąże się z oceną zakresu ustawowych zadań prezesa samorządowego kolegium odwoławczego. W komentarzu wskazano na ich mocne ograniczenie, ponieważ to organ nadzoru określa maksymalną liczbę etatowych członków lub zasady kształtowania wynagrodzeń pracowników (s. 51). Nie sposób zaprzeczyć powyższej konstatacji o ograniczonych kompetencjach kierowniczych prezesa wobec członków, jakie wynikają z przepisów prawa powszechnie obowiązującego, wystarczy wszakże przypomnieć, że jest to pozostałość zarzuconej koncepcji usądowienia tych jednostek organizacyjnych ${ }^{5}$. Warto natomiast podkreślić ustawowe możliwości prezesa do stworzenia autorskiego składu osobowego kolegium, co powinno zapobiegać ewentualnym konfliktom wewnątrz omawianego organu odwoławczego; problem w tym, że praktyka nie zawsze dostosowuje się

4 M. Gapski, W. Taras, Prezes samorzadowego kolegium odwoławczego i jego uprawnienia kierownicze wobec członków, [w:] Procesy kierowania w systemie administracji publicznej, red. J. Łukasiewicz, Rzeszów 2014, s. 114.

5 Zob. W. Taras, Samorzadowe kolegia odwoławcze (zagadnienia ustrojowe), [w:] Państwo, ustrój, samorząd terytorialny, red. M. Chmaj, Lublin 1997, s. 224-226. 
do teoretycznych modeli. Dobrze jest zwrócić uwagę na art. 11 ust. 1 pkt 9 ustawy z 1994 r. nakładający na prezesa kolegium obowiązek czuwania nad jednolitością jego orzecznictwa w porównaniu z nikłością praktycznych instrumentów pozostających do jego dyspozycji. Dlatego podkreśla się w doktrynie prawa publicznego, że najskuteczniejszym środkiem gwarantującym spójne orzekanie członków jest działalność sądów administracyjnych ${ }^{6}$.

Ponadto należy odnotować błąd w komentarzu do art. 35. Otóż wskazano, że ustawa weszła w życie po upływie 14 dni od dnia jej publikacji, czyli w dniu 5 grudnia 1994 r. (s. 106). Skoro ogłoszono ją w numerze Dziennika Ustaw z datą 21 listopada wskazanego roku, to zgodnie $\mathrm{z}$ regułą zawartą $\mathrm{w}$ art. 6 ust. 1 ustawy z dnia 20 lipca 2000 r. o ogłaszaniu aktów normatywnych i niektórych innych aktów prawnych ${ }^{7}$ dniem wejścia w życie był 6 grudnia 1994 r. $^{8}$ Nie można wykluczyć, że przyczyna wskazanej pomyłki sprowadza się do błędu pisarskiego oraz niechęci sporej grupy autorów (w tym niżej podpisanego) do wprowadzania zmian po korekcie wydawniczej.

Recenzowany komentarz został wydany przez cenione wydawnictwo C.H. Beck w serii „Ustawy w Praktyce”. Nie sądzę, aby wzbogacił on wiedzę członków samorządowych kolegiów odwoławczych z powodów, które starałem się wyjaśnić. Może jednak być przydatny dla nieco ambitniejszych studentów lub przyszłych pracowników tych organów odwoławczych, choć pod warunkiem, że będą mogli pozwolić sobie na spory wydatek finansowy.

M. Gapski, W. Taras, op. cit., s. 116.

T.j. Dz.U. 2017, poz. 1523.

8 Zob. np. G. Wierczyński, Redagowanie i ogłaszanie aktów normatywnych. Komentarz, Warszawa 2016, s. 878. 